\title{
Irrigation scheduling for green beans grown in clay loam soil under a drip irrigation system
}

\author{
Mohamed E Abuarab1, Salma M Hafez1, Mohamed M Shahein², Ahmed M Hassan', Mohamed BI El-Sawy³, \\ Mohamed M El-Mogy² and Emad A Abdeldaym² ${ }^{2}$ iD
}

\author{
'Agriculture Engineering Dept., Faculty of Agriculture, Cairo University, El-Gama St. 9, 12613 Giza, Egypt \\ ${ }^{2}$ Vegetable Crops Dept., Faculty of Agriculture, Cairo University, El-Gama St. 9, 12613 Giza, Egypt \\ ${ }^{3}$ Department of Horticulture, Faculty of Agriculture, Kafrelsheikh University, Kafrelsheikh, Egypt
}

An experimental field trial was conducted at El-Ayat, El-Giza Governorate, Egypt (latitude $30^{\circ} 11^{\prime} 13^{\prime \prime} \mathrm{N}$, longitude $31^{\circ} 41^{\prime} 38^{\prime \prime} \mathrm{E}$, and mean altitude $74 \mathrm{~m}$ above sea level) during the growing season of 2017 and 2018 . The study aimed to assess the suitable irrigation interval and applied water volume for drip-irrigated green beans, based on water production functions and water use-yield relationships. The field trial was arranged in a split-plot design with 3 irrigation intervals $\left(F_{1}, F_{2}\right.$ and $F_{3}$ irrigation events, once every 1,2 and 3 days, respectively) and 3 irrigation regimes $\left(\mathrm{I}_{1}: 1.00, \mathrm{I}_{2}: 0.80\right.$, and $\mathrm{I}_{3}: 0.60$ of the crop evapotranspiration, $\left.\mathrm{ET}_{\mathrm{c}}\right)$. The results showed that the yield and water use efficiency (WUE) increased with increasing irrigation interval. Maximum and minimum yield of 12030 and $4879 \mathrm{~kg} \cdot \mathrm{ha}^{-1}$ were obtained in $\mathrm{F}_{1} \mathrm{I}_{2}$ and $\mathrm{F}_{3} \mathrm{I}_{3}$ treatment, respectively, in the winter season of 2017, and were 12364 and $4678 \mathrm{~kg} \cdot \mathrm{ha}^{-1}$ for the corresponding treatments in the winter season of 2018. WUE ranged from $56.55 \mathrm{~kg} \cdot \mathrm{ha}^{-1} \cdot \mathrm{mm}^{-1}$ in $\mathrm{F}_{1} \mathrm{l}_{2}$ to $23.80 \mathrm{~kg} \cdot \mathrm{ha}^{-1} \cdot \mathrm{mm}^{-1}$ in $\mathrm{F}_{3} \mathrm{l}_{3}$. Plant growth parameters were significantly affected by the irrigation schedule. The highest plant growth parameters were obtained under $F_{1}$ and $F_{2}$. The seasonal yield response factors $\left(k_{y}\right)$ were 0.845 and 0.856 in 2017 and 2018 , respectively. The relationship between yield and seasonal crop ET was best explained by a power function for all irrigation schedules for both growing seasons. It is recommended that the $\mathrm{F}_{1} \mathrm{I}_{2}$ irrigation treatment is the suitable one for green beans grown under field conditions, in order to achieve the highest yield and WUE.

\section{INTRODUCTION}

By the year 2050, it is forecast that there will be a universal yearly water deficit of 640 billion $\mathrm{m}^{3}$ (Spears, 2003). Given that water shortages currently plague every country in North Africa and the Middle East, insufficient water supply for irrigation in these regions, even for short periods, will almost certainly become the norm rather than the exception. Thus, water scarcity has gained increasing importance on both scientific and political agendas. Because irrigation is the largest consumer of water, accounting for $71 \%$ of freshwater use worldwide, it is necessary for irrigation water management practices to shift from a focus on production per unit area to maximizing production per unit of water consumed (Fereres and Soriano, 2007).

Significant progress has been made in dissemination of drip irrigation systems, but coping with the looming water crisis requires further improvement in drip irrigation management. Many authors have shown that water use efficiency and crop productivity using a drip irrigation system might be improved by reducing the volume of water applied, to prevent water seeping away from the root zone (Hergert et al., 2016; Çolak et al., 2017; Coyago-Cruzrt et al., 2019; Vwioko et al., 2019). Thus, it is important to determine the actual water volume required for crop growth. Moreover, it is necessary to develop appropriate irrigation schedules to maximize crop production (El-Hendawy et al., 2008; Abuarab et al., 2019). Both evapotranspiration (ET) and crop coefficient $\left(K_{c}\right)$ are influenced by the climate, crop type and physiological growth stage of the crop (Testa et al., 2011). Deficit evapotranspiration is a technique to increase the water use efficiency. Deficit evapotranspiration could be manipulated through adopting new agricultural management practices. The target of deficit irrigation is to increase the water use efficiency for crops by reducing the irrigation water volume via reducing the number of irrigation events (Coyago-Cruz et al., 2019). The application of deficit irrigation interacts with the appropriate irrigation scheduling, which is verified in the field, since crop sensitivity to water stress throughout the growing season changes with the phenological stage (Istanbulluoglu, 2009). Furthermore, water deficit at particular stages of the growing season enhances fruit quality, despite the lack of productivity caused by water restrictions (Patanè and Cosentino, 2010). Drip irrigation has improved water use efficiency significantly by reducing the runoff and evaporation losses (Çolak et al. 2017). Recently, deficit irrigation has been proposed as a potential method to achieve high water use efficiency by different crops.

The combination of deficit irrigation and irrigation frequency is important to achieve the highest yield and water use efficiency. Ertek et al. (2004) reported that irrigation at $0.85 \mathrm{Kcp}$ and a 5-day irrigation interval are recommended for summer squash grown under loamy soil, in order to produce higher summer squash yield. Uçan et al. (2007) reported that the effects of irrigation water amount and plant water consumption are important to produce high yields and water use efficiency of sesame under clay loam soil. El-Hendawy and Schmidhalter (2010) reported that the relationship between

\section{CORRESPONDENCE}

Emad A Abdeldaym

\section{EMAIL}

emad.abdeldaym@agr.cu.edu.eg

\section{DATES}

Received: 17 November 2019

Accepted: 17 August 2020

\section{KEYWORDS}

irrigation schedule evapotranspiration drip irrigation green bean yield irrigation water use efficiency

\section{COPYRIGHT}

(c) The Author(s) Published under a Creative Commons Attribution 4.0 International Licence (CC BY 4.0) 
Table 1. Some soil properties of the experimental field

\begin{tabular}{|c|c|c|c|c|c|c|c|c|c|}
\hline \multirow[t]{2}{*}{ Soil depth $(\mathrm{cm})$} & \multicolumn{4}{|c|}{ Particle size distribution } & \multirow[t]{2}{*}{ Texture } & \multirow{2}{*}{$\begin{array}{c}\theta_{\mathrm{FC}} \\
\left(\mathrm{cm}^{3} \cdot \mathrm{cm}^{-3}\right)\end{array}$} & \multirow{2}{*}{$\begin{array}{c}\theta_{\mathrm{WP}} \\
\left(\mathrm{cm}^{3} \cdot \mathrm{cm}^{-3}\right)\end{array}$} & \multirow{2}{*}{$\begin{array}{c}\text { Bulk density } \\
\left(\mathrm{g} \cdot \mathrm{cm}^{-3}\right)\end{array}$} & \multirow[t]{2}{*}{$\mathrm{pH}$} \\
\hline & Coarse sand (\%) & Fine sand (\%) & Silt (\%) & Clay (\%) & & & & & \\
\hline $0-20$ & 5.50 & 18.30 & 38.50 & 37.70 & Clay loam & 43.4 & 22.3 & 1.30 & 7.92 \\
\hline $20-40$ & 7.40 & 19.20 & 37.80 & 35.60 & Clay loam & 43.6 & 22.5 & 1.30 & 7.88 \\
\hline $40-60$ & 7.30 & 18.30 & 38.50 & 35.90 & Clay loam & 44.0 & 23.7 & 1.29 & 7.89 \\
\hline
\end{tabular}

WUE and grain yield is often used for determining the optimal irrigation strategy for arid and semi-arid regions. High values of WUE are obtained for large yield values. Irrigation once every 2 days with $1.00 \mathrm{ET}_{\mathrm{c}}$ is recommended with adequate irrigation water. When the irrigation water is limited, irrigation once a day with $0.6 \mathrm{ET}_{\mathrm{c}}$ is recommended as the best irrigation schedule for drip-irrigated maize in sandy soils.

Sezen et al. (2005) demonstrated that irrigation water amount and irrigation frequency had a significant effect on yields of fieldgrown green beans under the Mediterranean climatic conditions in Turkey. Irrigation intervals and plant-pan coefficients had a significant effect on yield and quality of green bean. The maximum yield was obtained with a $2-3$ day irrigation interval and plant-pan coefficient of 1.00 , which had the highest water use. The results also indicated that WUE and IWUE values decreased with increasing irrigation interval.

The plant is very responsive to environmental conditions and abiotic factors such as temperature, humidity, precipitation and soil moisture, all of which can affect its yield and quality. Understanding the relationship between the plant and water consumption, as well as developing different management systems based on this knowledge, may help maximize the yield. Since water requirements of green beans have not been investigated sufficiently so far under arid conditions, irrigation water planning and management need to be studied.

The current study aims to assess the suitable irrigation interval and applied water volume (irrigation schedule) for drip-irrigated green beans, specified by water productivity functions and water use-yield relationships.

\section{MATERIALS AND METHODS}

\section{Open-field experiment}

A field experiment was conducted during the winter growing season of 2017 and 2018 at El-Ayat, El-Giza Governorate, Egypt (latitude $30^{\circ} 11^{\prime} 13^{\prime \prime} \mathrm{N}$, longitude $31^{\circ} 41^{\prime} 38^{\prime \prime} \mathrm{E}$, and mean altitude $74 \mathrm{~m}$ amsl). The soil of the experimental site is classified as clay loam. Physical and chemical properties of the experimental soil are given in Table 1. Irrigation water was obtained from a deep well located in the experimental area, with $\mathrm{pH} 7.43$ and an average electrical conductivity of $0.59 \mathrm{dS} \cdot \mathrm{m}^{-1}$.

\section{Weather conditions}

The field experiment was conducted in an area of arid climate with cool winters and humid summers with almost nil rainfall $(<20 \mathrm{~mm})$. The following climatic variables were recorded daily during both growing seasons: maximum, minimum and average air temperature, air relative humidity and sunshine hours. During the growing season (October-December), the maximum air temperature ranged from $20-30^{\circ} \mathrm{C}$ in 2017 and $19-28^{\circ} \mathrm{C}$ in 2018 , while the minimum ranged from 12 to $21^{\circ} \mathrm{C}$ and from 11 to $18^{\circ} \mathrm{C}$ in the $1^{\text {st }}$ and $2^{\text {nd }}$ growing seasons, respectively (Table 2 ).

\section{Crop administration}

Three seeds of green bean (Phaseolus vulgaris L.) were sown around each dripper on 12 October 2017 and 2018 (90 000 plants.ha ${ }^{-1}$ ).
Table 2. Meteorological data for El-Giza city during both growing seasons of 2017 and 2018

\begin{tabular}{clccc}
\hline \multirow{2}{*}{ Year } & Climatic parameters & \multicolumn{3}{c}{ Month } \\
\cline { 3 - 5 } & & October & November & December \\
\hline 2017 & $T_{\min }\left({ }^{\circ} \mathrm{C}\right)$ & 30 & 26.3 & 20 \\
& $T_{\max }\left({ }^{\circ} \mathrm{C}\right)$ & 26 & 21 & 16 \\
& $T_{\text {ave }}\left({ }^{\circ} \mathrm{C}\right)$ & 59.9 & 62 & 53 \\
& Relative humidity (\%) & 11.5 & 10.5 & 10.2 \\
& Sunshine (h) & 18 & 17 & 11 \\
2018 & $T_{\text {min }}\left({ }^{\circ} \mathrm{C}\right)$ & 28 & 26 & 19 \\
& $T_{\max }\left({ }^{\circ} \mathrm{C}\right)$ & 23 & 21 & 15 \\
& $T_{\text {ave }}\left({ }^{\circ} \mathrm{C}\right)$ & 57 & 59 & 56 \\
& Relative humidity (\%) & 57 & 10.3 \\
\hline & Sunshine (h) & 11.4 & 10.9 & \\
\hline
\end{tabular}

$T_{\text {min }}\left({ }^{\circ} \mathrm{C}\right)$ : minimum air temperature, $T_{\max }\left({ }^{\circ} \mathrm{C}\right)$ : maximum air temperature, $T_{\text {ave }}\left({ }^{\circ} \mathrm{C}\right)$ : average air temperature

Nitrogen (50 kg.ha-1), phosphate $\left(20 \mathrm{~kg} \cdot \mathrm{ha}^{-1}\right)$ and potassium $\left(41.5 \mathrm{~kg} \cdot \mathrm{ha}^{-1}\right)$ fertilizers were added in the form of ammonium sulphate $(20.5 \%)$, calcium superphosphate $(15.5 \%)$ and potassium sulphate $(48 \%)$. The fertilizers doses were added 2 weeks after planting at 6 equal weekly doses for nitrogen, while phosphate was added entirely before planting, and potassium was applied 5 weeks after planting in 2 equal biweekly doses. Hand harvesting was performed at approximately 70 days after planting.

\section{System installation and experimental treatments}

A split-plot design with 3 replicates was applied in both growing seasons. The irrigation interval treatments $\left(\mathrm{F}_{1}\right.$ : once every day, $\mathrm{F}_{2}$ : once every 2 days and $\mathrm{F}_{3}$ : once every 3 days) were assigned to the main plot. The irrigation regime treatments $\left(\mathrm{I}_{1}: 1.00 \mathrm{ET}_{\mathrm{c}}, \mathrm{I}_{2}\right.$ : $0.80 \mathrm{ET}_{\mathrm{c}}$ and $\mathrm{I}_{3}: 0.60 \mathrm{ET}_{\mathrm{c}}$ ) were allocated in the subplot (Fig. 1). Each plot had a gate valve and flow metre to control water application and to measure the discharge.

\section{The equilibrium of soil water and crop evapotranspiration}

Soil-water equilibrium and crop evapotranspiration $\left(\mathrm{ET}_{\mathrm{c}}\right)$ were calculated daily with computer software (Microsoft Excel-Based) by following the procedures set out in Food and Agriculture Organization Paper 56 (Allen et al., 1998). The inputs were daily weather data, including rainfall depth, irrigation dates and quantities, initial soil moisture content at crop emergence, crop and experimental site characterization (such as the date of planting, maturity, soil parameters such as field capacity, wilting point, available water and allowable depletion during and after initial stage, maximum root depth). The calculation steps, formulas and the coefficients used in the software are:

$$
I=\mathrm{ET}_{o}\left(K_{\mathrm{cb}}+K_{\mathrm{e}}\right)
$$

where $K_{\mathrm{cb}}$ is the basal crop coefficient, $K_{\mathrm{e}}$ is the soil evaporation coefficient and $\mathrm{ET}_{\mathrm{o}}$ is the daily reference evapotranspiration $\left(\mathrm{mm} \cdot \mathrm{day}^{-1}\right)$. Reference evapotranspiration was determined using the Penman-Monteith equation (Testa et al., 2011) by applying 


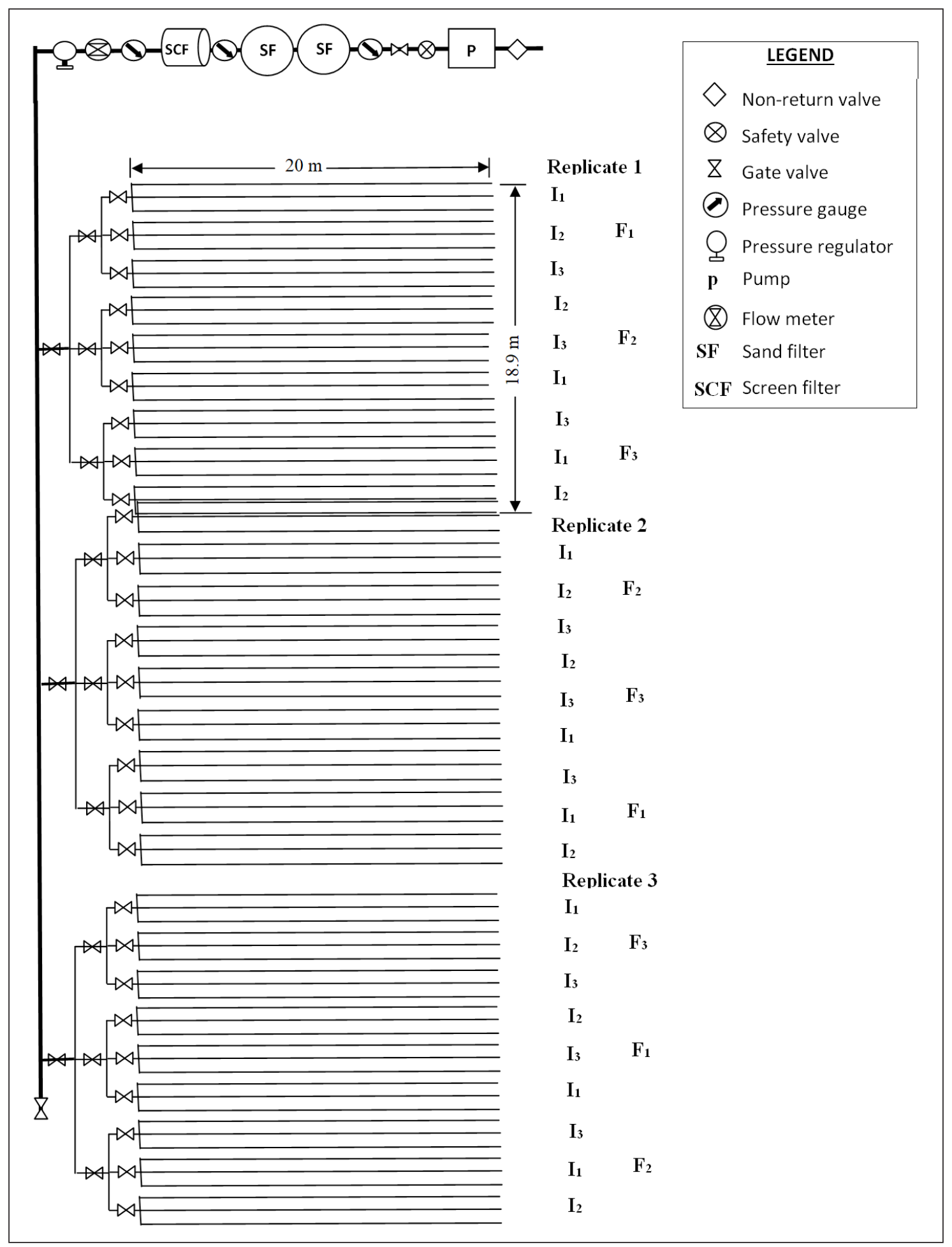

Figure 1. Schematic sketch of micro-irrigation system components and treatments

daily climatic parameters measured at a weather station within $500 \mathrm{~m}$ of the experimental area (Fig. 2):

$$
\mathrm{ET}_{\mathrm{o}}=\frac{0.408 \Delta\left(R_{n}+G\right)+\gamma\left(\frac{900}{\mathrm{~T}+273 \mathrm{U}_{2}\left(e_{s}-e_{a}\right)}\right)}{\Delta+\Upsilon\left(1+0.34 \mathrm{U}_{2}\right)}
$$

where $\mathrm{ET}_{\mathrm{o}}$ is the reference evapotranspiration $\left(\mathrm{mm} \cdot\right.$ day $\left.^{-1}\right), R_{\mathrm{n}}$ is the net radiation at the crop surface $\left(\mathrm{MJ} \cdot \mathrm{m}^{-2} \cdot \mathrm{day}^{-1}\right), G$ is the soil heat flux density $\left(\mathrm{MJ} \cdot \mathrm{m}^{-2} \cdot \mathrm{day}^{-1}\right), T$ is the mean daily air temperature at $2 \mathrm{~m}$ height $\left({ }^{\circ} \mathrm{C}\right), U_{2}$ is the wind speed at $2 \mathrm{~m}$ height $\left(\mathrm{m} \cdot \mathrm{s}^{-1}\right), e_{s}$ is the saturation vapour pressure $(\mathrm{kPa}), e_{a}$ is the actual vapour pressure $(\mathrm{kPa}), e_{s}-e_{a}$ is the saturation vapour pressure deficit $(\mathrm{kPa}), \Delta$ is the slope of the saturation vapour pressure curve $\left(\mathrm{kPa} \cdot{ }^{\circ} \mathrm{C}^{-1}\right)$, and $\gamma$ is the psychometric constant $\left(\mathrm{kPa} \cdot{ }^{\circ} \mathrm{C}^{-1}\right)$.

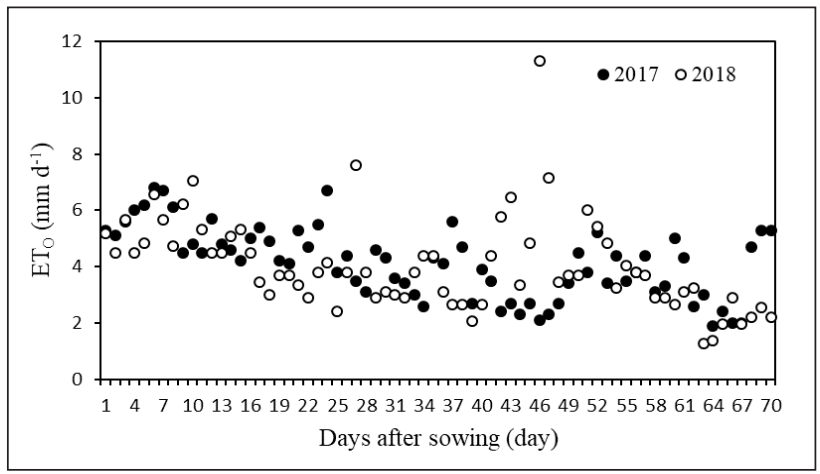

Figure 2. Daily $\mathrm{ET}_{\mathrm{O}}$ during crop season 
The applied values of $K_{\mathrm{cb}}$ for the initial, mid- and late-season stages of green bean are $0.15,1.05$ and 0.97 , respectively, which represent the recommended values for a sub-humid climate $\left(\mathrm{RH}_{\min }\right.$ of approximately $\left.45 \%\right)$ with a moderate wind speed $\left(U_{2}\right.$ approximately $\left.2 \mathrm{~m} \cdot \mathrm{s}^{-1}\right)$. The average evaporation coefficient $\left(K_{\mathrm{e}}\right)$ values for both growing seasons are $0.31,1.02$ and 0.35 for the initial, middle and late stages, respectively. The average $K_{C}$ values were $0.30,1.30$ and 0.35 for both growing seasons for the initial, mid- and late-season stages, respectively (Testa et al., 2011).

To guarantee full germination, $95.4 \mathrm{~mm}$ of irrigation water was added to all treatments at planting, with the addition of a supplementary volume of water applied 20 days after sowing to ensure full seedling growth. Subsequently, the application of irrigation treatments began in 30 days, according to the irrigation schedule treatments.

Actual crop evapotranspiration under the different irrigation treatments was estimated using the formula for soil-water equilibrium (Heermann, 1985):

$$
\mathrm{ET}=I+P+C_{\mathrm{r}}-R-D \pm \Delta S
$$

where ET is the seasonal crop evapotranspiration $(\mathrm{mm}), I$ is the irrigation water amount $(\mathrm{mm}), P$ is the precipitation $(\mathrm{mm}), C_{\mathrm{r}}$ is the capillary rise $(\mathrm{mm}), R$ is the runoff $(\mathrm{mm}), D$ is the drainage water $(\mathrm{mm})$, and $\Delta S$ is the change in soil water storage in a given time period within the plant rooting zone $(\mathrm{mm})$.

To calculate $\Delta S$, gravimetric measurements were used to determine moisture content in the soil profile. The soil moisture content was monitored biweekly before irrigation for all treatments, for each $10 \mathrm{~cm}$ soil layer, down to $40 \mathrm{~cm}$. Soil samples were taken directly beneath emitters. Both $P$ and $C_{\mathrm{r}}$ were set at zero because there was no rainfall throughout the growing season and there was no capillary rise from the groundwater. The surface runoff value was modest because the added irrigation water was controlled by drip irrigation. When the soil moisture content in the root zone $(0-40 \mathrm{~cm})$ was above field capacity, the surplus water would likely percolate to the deeper soil layers as deep percolation $(D)$. The amount of $D$ water equals total available water at $0-40 \mathrm{~cm}$ soil depth before irrigation in $\mathrm{mm}+$ applied irrigation water in $\mathrm{mm}$ soil water held in field capacity in mm (Kanber et al., 1993; Zhang et al., 2019).

\section{Evaluation of lateral lines}

Each subplot $\left(42 \mathrm{~m}^{2}\right)$ consisted of 3 polyethylene lateral drip lines $(16 \mathrm{~mm}$ in diameter and $0.3 \mathrm{~m}$ emitter spacing, Euro drip, Greece) with a length of $20 \mathrm{~m}$. The lateral line was laid out along each green bean row at $0.7 \mathrm{~m}$. The hydraulic characteristics of lateral drip lines were tested at the National Irrigation Laboratory of Agricultural Engineering Research Institute (AERI), Dokki, Giza. The water application uniformity was calculated from the coefficient of variation $(v)$ and emission uniformity (EU) by adopting Eqs 4 and 5 (Keller and Karmeli, 1975) as follows:

$$
\begin{gathered}
v=\frac{s d}{q_{a}} \\
E U=100\left(1.0-1.27 \frac{v}{\sqrt{N_{p}^{\prime}}}\right) \frac{q_{n}}{q_{a}}
\end{gathered}
$$

where sd is the standard deviation of emitter discharge $\left(\mathrm{L} \cdot \mathrm{h}^{-1}\right) ; q_{\mathrm{a}}$ is the average discharge of tested emitters $\left(\mathrm{L} \cdot \mathrm{h}^{-1}\right), N_{\mathrm{p}}^{\prime}$ is the number of emitters per plant, $q_{\mathrm{n}}$ is the minimum discharge $\left(\mathrm{L} \cdot \mathrm{h}^{-1}\right)$, and $q_{\mathrm{a}}$ is the average discharge of all emitters $\left(\mathrm{L} \cdot \mathrm{h}^{-1}\right)$ (Table 3 ). The micro-irrigation system was rated in accordance with the standard classification of the American Society of Agricultural Engineering, which ranges from excellent to unacceptable (Smajstrla et al., 1990).
Table 3. Hydraulic properties of lateral drip lines

\begin{tabular}{lc}
\hline Characteristics & T-tape \\
\hline Wall thickness $(\mathrm{mm})$ & 0.3 \\
Internal diameter $(\mathrm{mm})$ & 16 \\
Pressure compensating & No \\
Minimum operating pressure $(\mathrm{kPa})$ & 30 \\
Maximum operating pressure $(\mathrm{kPa})$ & 105 \\
Emitter flowrate $\left(\mathrm{L} \cdot \mathrm{h}^{-1}\right)$ & 4.0 \\
Emitter spacing $(\mathrm{cm})$ & 30.0 \\
Lateral spacing $(\mathrm{cm})$ & 70.0 \\
Lateral placement depth $(\mathrm{cm})$ & 20.0 \\
Exponent $(\mathrm{x})$ & 0.5 \\
$N$ & 2.96 \\
EU & 96 \\
\hline
\end{tabular}

\section{Water use efficiencies}

Water use efficiency (WUE) and irrigation water use efficiency (IWUE) values were calculated according to the equations of Howell et al. (1990) as follows:

$$
\begin{aligned}
\text { WUE } & =\frac{Y}{\mathrm{ET}} \\
\text { IWUE } & =\frac{Y}{I}
\end{aligned}
$$

where WUE is the water use efficiency $\left(\mathrm{kg} \cdot \mathrm{ha}^{-1} \cdot \mathrm{mm}^{-1}\right), Y$ is the economic yield ( $\left.\mathrm{t} \cdot \mathrm{ha}^{-1}\right)$, ET is the plant water consumption $(\mathrm{mm})$, and $I$ is the irrigation water applied $(\mathrm{mm})$. Relationships between evapotranspiration data and seasonal crop productivity were extracted from field trials. The percentage of the irrigation water applied for crop evapotranspiration $\left(I_{\mathrm{rc}}\right)$ was estimated for each irrigation treatment using the following equation (Ertek et al. 2004):

$$
I_{\mathrm{rc}}=\left(\frac{I}{\mathrm{ET}}\right) \times 100
$$

\section{Water use-yield relationships and the yield response factor for green bean}

Regression analysis was used to evaluate the water use-yield relationships derived from seasonal crop evapotranspiration and productivity data acquired from the field trials. The yield response factor $\left(k_{y}\right)$ for each irrigation interval for both growing seasons represents the relationship between relative yield reduction $\left(1-Y_{\mathrm{a}} / Y_{\mathrm{m}}\right)$ of green bean and the relative deficit in the evapotranspiration $\left(1-\mathrm{ET}_{\mathrm{a}} / \mathrm{ET}_{\mathrm{m}}\right)$, specified by using the equation of Doorenbos and Kassam (1986):

$$
\left(1-\frac{Y_{\mathrm{a}}}{Y_{\mathrm{m}}}\right)=k_{\mathrm{y}}\left(1-\frac{\mathrm{ET}_{\mathrm{a}}}{\mathrm{ET}_{\mathrm{m}}}\right)
$$

where $\mathrm{ET}_{\mathrm{a}}$ and $\mathrm{ET}_{\mathrm{m}}$ are the actual and maximum seasonal crop evapotranspiration $(\mathrm{mm})$, respectively, and $Y_{\mathrm{a}}$ and $Y_{\mathrm{m}}$ are the corresponding actual and maximum yields $\left(\mathrm{kg} \cdot \mathrm{ha}^{-1}\right)$.

\section{Assessment criteria}

Forty-five days after sowing, 5 plants at the harvest stage were randomly selected from each treatment for measuring vegetative criteria (plant height, leaves number per plant, fresh weight and leaves chlorophyll percentage). Mature green bean pods were harvested from the centre of 3 rows in each plot. Harvesting was performed for an area equal to $12.6 \mathrm{~m}^{2}$ (3 rows, each row a length of $6 \mathrm{~m}$ ). The selected plants that were randomly selected from each irrigation treatment were separated individually to determine the plant dry weight. 
Table 4. Assessment of green bean crop evapotranspiration for various treatments and growing seasons through the application of the water balance formula

\begin{tabular}{|c|c|c|c|c|c|c|c|c|}
\hline Year & Treatments & & $I(\mathrm{~mm})$ & $P(\mathrm{~mm})$ & $D(\mathrm{~mm})$ & $\Delta S(\mathrm{~mm})$ & $\mathrm{ET}_{\mathrm{c}}(\mathrm{mm})$ & $I_{\mathrm{rc}}(\%)$ \\
\hline \multirow[t]{9}{*}{2017} & $F_{1}$ (once in 1 day) & $1.00 \mathrm{ET}$ & 274.80 & 0.00 & 18.28 & -10.33 & 271.16 & 101.18 \\
\hline & & $0.80 \mathrm{ET}$ & 202.00 & 0.00 & 0.00 & -15.30 & 217.30 & 92.96 \\
\hline & & $0.60 \mathrm{ET}$ & 147.65 & 0.00 & 0.00 & -15.35 & 163.00 & 90.59 \\
\hline & $\mathrm{F}_{2}$ (once in 2 days) & $1.00 \mathrm{ET}$ & 269.08 & 0.00 & 0.00 & -17.32 & 286.40 & 93.95 \\
\hline & & $0.80 \mathrm{ET}$ & 213.20 & 0.00 & 0.00 & -15.90 & 229.10 & 93.06 \\
\hline & & $0.60 \mathrm{ET}$ & 156.82 & 0.00 & 0.00 & -14.98 & 171.80 & 91.28 \\
\hline & $\mathrm{F}_{3}$ (once in 3 days) & $1.00 \mathrm{ET}$ & 307.87 & 0.00 & 0.00 & -19.13 & 327.00 & 94.15 \\
\hline & & $0.80 \mathrm{ET}$ & 243.96 & 0.00 & 0.00 & -17.64 & 261.60 & 93.26 \\
\hline & & $0.60 \mathrm{ET}$ & 178.12 & 0.00 & 0.00 & -18.08 & 196.20 & 90.78 \\
\hline \multirow[t]{9}{*}{2018} & $\mathrm{~F}_{1}$ (once in 1 day) & $1.00 \mathrm{ET}$ & 274.80 & 0.00 & 19.45 & -10.74 & 269.65 & 101.48 \\
\hline & & $0.80 \mathrm{ET}$ & 202.00 & 0.00 & 0.00 & -16.83 & 218.83 & 92.66 \\
\hline & & $0.60 \mathrm{ET}$ & 147.65 & 0.00 & 0.00 & -16.73 & 164.38 & 90.19 \\
\hline & $\mathrm{F}_{2}$ (once in 2 days) & $1.00 \mathrm{ET}$ & 269.08 & 0.00 & 0.00 & -18.73 & 287.80 & 93.75 \\
\hline & & $0.80 \mathrm{ET}$ & 213.20 & 0.00 & 0.00 & -16.22 & 229.42 & 93.06 \\
\hline & & $0.60 \mathrm{ET}$ & 156.82 & 0.00 & 0.00 & -15.28 & 172.10 & 90.39 \\
\hline & $\mathrm{F}_{3}$ (once in 3 days) & $1.00 \mathrm{ET}$ & 307.87 & 0.00 & 0.00 & -20.85 & 328.72 & 93.75 \\
\hline & & $0.80 \mathrm{ET}$ & 243.96 & 0.00 & 0.00 & -18.70 & 262.66 & 92.86 \\
\hline & & $0.60 \mathrm{ET}$ & 178.12 & 0.00 & 0.00 & -18.45 & 196.56 & 90.19 \\
\hline
\end{tabular}

\section{Statistical analysis}

All measurements in this study were analysed using an analysis of variance (ANOVA) appropriate for a randomized complete block split-plot design with irrigation interval as the main plot, irrigation regime as the subplots, and replicates as blocks. The mean square of the product between the irrigation interval and irrigation regime was used as the error term to test the interaction between both factors. The least significant difference (LSD) of Duncan's test was used to define statistically significant differences between average groups in the ANOVA. Probability levels lower than 0.05 were significant. All analyses were performed using the MSTAT program (MSTAT is written in the C programming language and runs on DOS compatible machines) (Freed et al., 1989). Power and linear regression analyses were performed to investigate the relationship between yield and evapotranspiration and the best relationship between yield and WUE. Regression analyses were performed using Microsoft Excel 2010.

\section{RESULTS AND DISCUSSION}

\section{Seasonal crop evapotranspiration}

Daily evapotranspiration $\left(\mathrm{ET}_{\mathrm{c}}\right)$ of green bean ranged from 1.90$8.57 \mathrm{~mm} \cdot \mathrm{d}^{-1}$ in 2017 and $1.51-15.39 \mathrm{~mm} \cdot \mathrm{d}^{-1}$ in 2018 (Fig. 3). Seasonal crop $\mathrm{ET}_{\mathrm{c}}$ of green bean varied from $163 \mathrm{~mm}$ in $\mathrm{F}_{1} \mathrm{I}_{3}$ to $327 \mathrm{~mm}$ in $\mathrm{F}_{3} \mathrm{I}_{1}$ treatments in 2017 and from $164 \mathrm{~mm}$ in $\mathrm{F}_{1} \mathrm{I}_{3}$ to $328.72 \mathrm{~mm}$ in $\mathrm{F}_{3} \mathrm{I}_{1}$ treatments in 2018. During both seasons, the crop $\mathrm{ET}_{\mathrm{c}}$ values increased with both decreasing irrigation regime and decreasing interval (Table 4). Borošic et al. (2000) found that the seasonal crop evapotranspiration $\left(\mathrm{ET}_{\mathrm{c}}\right)$ of green bean was $400 \mathrm{~mm}$ in Zagreb. The variation in $\mathrm{ET}_{\mathrm{c}}$ values could have resulted from the varying irrigation schedules utilized and diverse climate conditions. Sezen et al. (2008) demonstrated that $\mathrm{ET}_{\mathrm{c}}$ values of green bean ranged from $253 \mathrm{~mm}$ to $338 \mathrm{~mm}$, and they found that the seasonal crop evapotranspiration values increased with both decreasing irrigation regime and decreasing interval.

During both growing season of green beans, the $\mathrm{ET}_{\mathrm{c}}$ values were less than the amount of irrigation water applied $(I)$ for $\mathrm{F}_{1} \mathrm{I}_{1}$ treatment. In addition, the $D$ values for this treatment were lower

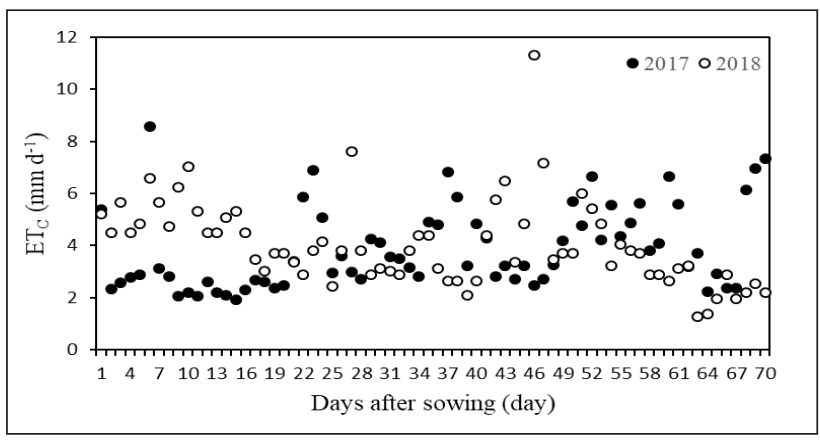

Figure 3. Daily crop evapotranspiration of green beans during both growing seasons

than for other treatments (Table 4). There are two explanations for this observation. First, the irrigation treatments, which included the addition of a large volume of water, limited the irrigation period when combined with higher irrigation frequency treatments (i.e., $F_{1} I_{1}$ ). The water extracted through the roots did not correspond with the volume of irrigation water applied, resulting in further deep percolation losses downward through the root zone. Secondly, we found that when green beans are cultivated in a clay loam soil, the plants extract most of the necessary water from a depth of zero to $20 \mathrm{~cm}$, which is where nearly $85 \%$ of the total length of the roots of green beans is concentrated. Therefore, the moisture content of the soil in the treatment $F_{1} I_{1}$ was higher before the harvest when compared with the other treatments, and thus the deep percolation loss values were lower for other treatments (with the opposite being true for $I_{\mathrm{rc}}$ ).

\section{Yield and water use efficiencies}

In the growth season of 2017, the maximum yield of $12030 \mathrm{~kg} \cdot \mathrm{ha}^{-1}$ was obtained under the $\mathrm{F}_{1} \mathrm{I}_{2}$ treatment, followed by the $\mathrm{F}_{2} \mathrm{I}_{1}, \mathrm{~F}_{1} \mathrm{I}_{1}$ and $\mathrm{F}_{3} \mathrm{I}_{1}$ treatments, with 10827,10693 , and $10559 \mathrm{~kg} \cdot \mathrm{ha}^{-1}$, respectively, while the minimum yield of $4879 \mathrm{~kg} \cdot \mathrm{ha}^{-1}$ was obtained under the $\mathrm{F}_{3} \mathrm{I}_{3}$ treatment. In the growth season of 2018, the maximum yield of $12364 \mathrm{~kg} \cdot \mathrm{ha}^{-1}$ was obtained in the $\mathrm{F}_{1} \mathrm{I}_{2}$ treatment, followed by $F_{2} I_{1}, F_{1} I_{1}$ and $F_{3} I_{1}$ treatments with yields of 10893,10827 and 
Table 5. The influence of irrigation schedule on yield, IWUE and WUE during both growing seasons of 2017 and 2018

\begin{tabular}{|c|c|c|c|c|c|c|c|c|}
\hline \multirow{2}{*}{$\begin{array}{l}\text { Irrigation } \\
\text { frequency }\end{array}$} & \multicolumn{4}{|c|}{2017} & \multicolumn{4}{|c|}{2018} \\
\hline & $1.00 \mathrm{ET}\left(\mathrm{I}_{1}\right)$ & $0.80 \mathrm{ET}\left(\mathrm{I}_{2}\right)$ & $0.60 \mathrm{ET}\left(\mathrm{I}_{3}\right)$ & Mean & $1.00 \mathrm{ET}\left(\mathrm{I}_{1}\right)$ & $0.80 \mathrm{ET}\left(\mathrm{I}_{2}\right)$ & $0.60 \mathrm{ET}\left(\mathrm{I}_{3}\right)$ & Mean \\
\hline \multicolumn{9}{|c|}{ Yield $\left(\mathbf{k g} \cdot \mathrm{ha}^{-1}\right)$} \\
\hline $\mathrm{F}_{1}$ (once in 1 day) & $10693 \mathrm{~b}$ & $12030 \mathrm{a}$ & 6817 e & $9846.67 a$ & 10827 b & 12364 a & 6683 e & $9958 a$ \\
\hline $\mathrm{F}_{2}$ (once in 2 days) & $10827 b$ & $9223 c$ & $5614 f$ & $8554.67 b$ & $10893 b$ & $9022 \mathrm{c}$ & $5680 \mathrm{f}$ & $8532 b$ \\
\hline $\mathrm{F}_{3}$ (once in 3 days) & $10559 \mathrm{~b}$ & $8020 d$ & $4879 \mathrm{~g}$ & $7819.33 c$ & $10760 \mathrm{~b}$ & $7686 d$ & $4678 \mathrm{~g}$ & $7708 \mathrm{c}$ \\
\hline Mean & $10693 a$ & 9757.67 b & $5770 \mathrm{c}$ & & $10826.67 a$ & $9690.67 \mathrm{~b}$ & $5680.33 c$ & \\
\hline LSD (0.05) & $F=1364$ & $\mathrm{ET}=283.4$ & $F \times \mathrm{ET}=1817$ & & $F=1477$ & $\mathrm{ET}=433.7$ & $F \times \mathrm{ET}=595.3$ & \\
\hline \multicolumn{9}{|c|}{ IWUE (kg $\left.\cdot \mathrm{ha}^{-1} \cdot \mathrm{mm}^{-1}\right)$} \\
\hline $\mathrm{F}_{1}$ (once in 1 day) & $38.91 \mathrm{~d}$ & $59.55 \mathrm{a}$ & $46.17 b$ & $48.21 \mathrm{a}$ & $39.40 \mathrm{~d}$ & $61.21 \mathrm{a}$ & $45.26 b$ & $48.62 \mathrm{a}$ \\
\hline $\mathrm{F}_{2}$ (once in 2 days) & $40.24 \mathrm{~d}$ & $43.26 c$ & $35.80 \mathrm{e}$ & 39.77 b & $40.48 d$ & $42.32 \mathrm{c}$ & $36.22 \mathrm{e}$ & $39.67 \mathrm{~b}$ \\
\hline $\mathrm{F}_{3}$ (once in 3 days) & 34.30 ef & $32.87 \mathrm{f}$ & $27.39 \mathrm{~g}$ & $31.52 \mathrm{c}$ & $34.95 \mathrm{e}$ & $31.50 \mathrm{f}$ & $26.26 \mathrm{~g}$ & $30.91 \mathrm{c}$ \\
\hline Mean & $37.82 \mathrm{~b}$ & $45.23 \mathrm{a}$ & $36.45 c$ & & $38.28 b$ & $45.01 \mathrm{a}$ & $35.92 \mathrm{c}$ & \\
\hline LSD (0.05) & $F=7.715$ & $\mathrm{ET}=1.173$ & $F \times \mathrm{ET}=2.033$ & & $F=8.256$ & $\mathrm{ET}=0.958$ & $F \times E T=1.66$ & \\
\hline \multicolumn{9}{|c|}{ WUE $\left(\mathrm{kg} \cdot \mathrm{ha}^{-1} \cdot \mathrm{mm}^{-1}\right)$} \\
\hline $\mathrm{F}_{1}$ (once in 1 day) & $39.43 c$ & $55.36 \mathrm{a}$ & $41.82 \mathrm{~b}$ & $45.54 \mathrm{a}$ & $40.15 \mathrm{~b}$ & $56.50 \mathrm{a}$ & $40.66 \mathrm{~b}$ & $45.77 \mathrm{a}$ \\
\hline $\mathrm{F}_{2}$ (once in 2 days) & $37.80 \mathrm{~d}$ & $40.26 \mathrm{c}$ & $32.68 \mathrm{e}$ & $36.91 \mathrm{~b}$ & $37.85 \mathrm{c}$ & $39.33 \mathrm{bc}$ & $33.00 \mathrm{~d}$ & $36.73 \mathrm{~b}$ \\
\hline $\mathrm{F}_{3}$ (once in 3 days) & $32.29 \mathrm{e}$ & $30.66 \mathrm{f}$ & $24.87 \mathrm{~g}$ & $29.27 c$ & $32.73 d$ & $29.26 \mathrm{e}$ & $23.80 \mathrm{f}$ & $28.60 \mathrm{c}$ \\
\hline Mean & $36.51 \mathrm{~b}$ & $42.09 \mathrm{a}$ & $33.12 \mathrm{c}$ & & $36.91 \mathrm{~b}$ & $41.70 \mathrm{a}$ & $32.49 c$ & \\
\hline $\operatorname{LSD}(0.05)$ & $F=1.151$ & $\mathrm{ET}=3.343$ & $F \times \mathrm{ET}=5.790$ & & $F=6.586$ & $\mathrm{ET}=0.932$ & $F \times \mathrm{ET}=1.62$ & \\
\hline
\end{tabular}

Means followed by the same letter are not significantly different from one another based on Duncan's protected LSD test at $P \leq 0.05$

$10760 \mathrm{~kg} \cdot \mathrm{ha}^{-1}$, respectively, while the lowest yield of $4678 \mathrm{~kg} \cdot \mathrm{ha}^{-1}$ was obtained from the $\mathrm{F}_{3} \mathrm{I}_{3}$ treatment (Table 5).

In both growing seasons, green bean yield decreased significantly as the irrigation interval increased $\left(\mathrm{I}_{3}\right)$ for a given $\mathrm{ET}_{c}$. The $\mathrm{F}_{1} \mathrm{I}_{2}$ treatment realized the highest yield in both growing seasons. Thus, it is recommended that green beans be irrigated once a day using the irrigation regime at $0.80 \mathrm{ET}_{c}$. The seasonal irrigation water requirement values for green beans in the $\mathrm{F}_{1} \mathrm{I}_{2}$ treatment were 217.3 and $218.83 \mathrm{~mm}$ for the growing seasons of 2017 and 2018, respectively. The results indicate that the yield of drip-irrigated green beans might be improved by applying a suitable irrigation schedule. Therefore, the maximum yield of $\mathrm{F}_{1} \mathrm{I}_{2}$ treatment can be attributed to the maintenance of enough available soil water content in the root zone without deep percolation and/or poor aeration conditions.

Irrigation water use efficiency (IWUE) values varied from a minimum of $27.39 \mathrm{~kg} \cdot \mathrm{ha}^{-1} \cdot \mathrm{mm}^{-1}$ for the $\mathrm{F}_{3} \mathrm{I}_{3}$ treatment to a maximum of $59.55 \mathrm{~kg} \cdot \mathrm{ha}^{-1} \cdot \mathrm{mm}^{-1}$ for the $\mathrm{F}_{1} \mathrm{I}_{2}$ treatment in the growing season of 2017. In the growing season of 2018, IWUE values ranged from a minimum of $26.26 \mathrm{~kg} \cdot \mathrm{ha}^{-1} \cdot \mathrm{mm}^{-1}$ for the $\mathrm{F}_{3} \mathrm{I}_{3}$ treatment to a maximum of $61.21 \mathrm{~kg} \cdot \mathrm{ha}^{-1} \cdot \mathrm{mm}^{-1}$ for the $\mathrm{F}_{1} \mathrm{I}_{2}$ treatment. The maximum and minimum of water use efficiency (WUE) in the growing season of 2017 was $55.36 \mathrm{~kg} \cdot \mathrm{ha}^{-1} \cdot \mathrm{mm}^{-1}$ and $24.87 \mathrm{~kg} \cdot \mathrm{ha}^{-1} \cdot \mathrm{mm}^{-1}$ for the $\mathrm{F}_{1} \mathrm{I}_{2}$ and $\mathrm{F}_{3} \mathrm{I}_{3}$ treatments, respectively. The corresponding values were $56.50 \mathrm{~kg} \cdot \mathrm{ha}^{-1} \cdot \mathrm{mm}^{-1}$ and 23.80 $\mathrm{kg} \cdot \mathrm{ha}^{-1} \cdot \mathrm{mm}^{-1}$ in the $\mathrm{F}_{1} \mathrm{I}_{2}$ and $\mathrm{F}_{3} \mathrm{I}_{3}$ treatments, respectively, in the $2^{\text {nd }}$ season. The obtained results showed that the WUE and IWUE values increased with increased irrigation interval. In general, several factors affect the WUE, such as irrigation interval, nutritive elements, soil salinity and soil-borne diseases (Abdelaziz et al., 2019; Abuarab et al., 2019; Atia et al., 2019; El-Mogy et al., 2019; Mahmoud et al., 2019).

These results indicated that although irrigation rate is vitally important for enhancing WUEs, irrigation regime is instead often crucial for maximizing yield per unit water. This finding might be attributed to the drip irrigation interval determining the soil moisture content and its distribution with depth in the water accumulation zone that develops around the emitter and, consequently, the amount of water percolating under the root zone as well as the amount of water uptake by the roots (Assouline, 2002; Wan and Kang, 2006). Therefore, frequent low rates of irrigation $\left(\mathrm{F}_{1} \mathrm{I}_{2}\right)$ were more effective for increasing irrigation efficiencies than were infrequent high irrigation rates $\left(\mathrm{F}_{3} \mathrm{I}_{1}\right)$ (Table 5).

This finding is due to the $\mathrm{F}_{3} \mathrm{I}_{1}$ treatment realizing remarkable fluctuations in soil water in the root zone, bringing about cyclic water stress for green bean root growth before the next irrigation event, and excessive water percolation owing to the amount of water applied at each event being much higher than the soil-water storage capacity. By contrast, the $\mathrm{F}_{1} \mathrm{I}_{2}$ treatment appears to provide the suitable available soil water content in the root zone without water percolation.

\section{Vegetative growth and pod parameters}

All vegetative growth and pod parameters were significantly affected by the irrigation schedule (Tables 6 and 7). The highest vegetative growth parameters and yield, averaged across all irrigation treatments, were obtained when the irrigation interval is small $\left(\mathrm{F}_{1}\right.$ and $\left.\mathrm{F}_{2}\right)$. As averaged for both seasons, the irrigation interval for treatment $\mathrm{F}_{3}$ resulted in reductions in all the vegetative growth parameters compared to the $\mathrm{F}_{1}$ treatment. These reductions were $15.82 \%$ and $25.44 \%$ of pod number per plant, $20.55 \%$ and $22.88 \%$ of pod weight per plant (Table 7), $18.60 \%$ and $29.89 \%$ of plant height, $40.57 \%$ and $44.67 \%$ of fresh weight, and $30.67 \%$ and $40.22 \%$ of dry weight, in the $1^{\text {st }}$ and $2^{\text {nd }}$ seasons, respectively (Table 6). In both growing seasons, $0.80 \mathrm{ET}\left(\mathrm{I}_{2}\right)$ and $0.60 \mathrm{ET}\left(\mathrm{I}_{3}\right)$ consistently resulted in lower yields than $1.00 \mathrm{ET}\left(\mathrm{I}_{1}\right)$ treatments, except for $F_{1} I_{2}$, which had the highest vegetative growth parameter values for most parameters (Table 6). Boutraa and Sanders (2001) stated that water stress through the vegetative growth stage and prior to pod establishment has the largest effect on limiting green bean yield. 
Table 6. The influence of irrigation schedule on green bean vegetative growth and pod parameters in the growing season of 2017 and 2018

\begin{tabular}{|c|c|c|c|c|c|c|c|c|}
\hline \multirow{2}{*}{$\begin{array}{l}\text { Irrigation } \\
\text { frequency }\end{array}$} & \multicolumn{4}{|c|}{2017} & \multicolumn{4}{|c|}{2018} \\
\hline & $1.00 \mathrm{ET}\left(\mathrm{I}_{1}\right)$ & $0.80 \mathrm{ET}\left(\mathrm{I}_{2}\right)$ & $0.60 \mathrm{ET}\left(\mathrm{I}_{3}\right)$ & Mean & $1.00 \mathrm{ET}\left(\mathrm{I}_{1}\right)$ & $0.80 \mathrm{ET}\left(\mathrm{I}_{2}\right)$ & $0.60 \mathrm{ET}\left(\mathrm{I}_{3}\right)$ & Mean \\
\hline \multicolumn{9}{|c|}{ Fresh weight (g) } \\
\hline $\mathrm{F}_{1}$ (once in 1 day) & $15.15 b$ & $20.20 \mathrm{a}$ & $10.25 d$ & $15.20 \mathrm{a}$ & $18.50 \mathrm{a}$ & $18.00 \mathrm{a}$ & $11.20 \mathrm{~d}$ & $15.90 \mathrm{a}$ \\
\hline $\mathrm{F}_{2}$ (once in 2 days) & $12.45 \mathrm{C}$ & $15.00 \mathrm{~b}$ & $8.00 \mathrm{e}$ & $11.82 \mathrm{~b}$ & $15.00 \mathrm{~b}$ & $15.15 b$ & $10.00 \mathrm{e}$ & $13.38 \mathrm{~b}$ \\
\hline $\mathrm{F}_{3}$ (once in 3 days) & $10.10 \mathrm{~d}$ & $12.50 \mathrm{c}$ & $5.10 \mathrm{f}$ & $9.23 c$ & $10.05 \mathrm{e}$ & $12.00 \mathrm{c}$ & $5.05 \mathrm{f}$ & $9.033 c$ \\
\hline Mean & $12.57 \mathrm{~b}$ & $15.90 \mathrm{a}$ & $7.783 \mathrm{c}$ & & $14.52 \mathrm{~b}$ & $15.05 \mathrm{a}$ & $8.75 \mathrm{c}$ & \\
\hline $\operatorname{LSD}(0.05)$ & $F=0.4763$ & $I=0.4654$ & $F \times I=0.806$ & & $F=0.3234$ & $I=0.323$ & $F \times I=0.560$ & \\
\hline \multicolumn{9}{|c|}{ Leaf number } \\
\hline $\mathrm{F}_{1}$ (once in 1 day) & $19.00 \mathrm{~cd}$ & $24.00 \mathrm{a}$ & $11.00 \mathrm{f}$ & $18.00 \mathrm{a}$ & $18.00 \mathrm{~cd}$ & $21.50 \mathrm{ab}$ & $9.00 \mathrm{e}$ & $16.17 \mathrm{~b}$ \\
\hline $\mathrm{F}_{2}$ (once in 2 days) & $20.50 \mathrm{bc}$ & $17.50 \mathrm{~d}$ & $14.50 \mathrm{e}$ & $17.50 \mathrm{a}$ & $23.50 \mathrm{a}$ & $20.50 \mathrm{abc}$ & $17.00 \mathrm{~d}$ & $20.33 a$ \\
\hline $\mathrm{F}_{3}$ (once in 3 days) & $19.50 \mathrm{bcd}$ & $22.00 \mathrm{ab}$ & $9.00 \mathrm{f}$ & $16.83 \mathrm{a}$ & $20.00 \mathrm{bcd}$ & $23.00 \mathrm{ab}$ & $8.50 \mathrm{e}$ & $17.17 \mathrm{~b}$ \\
\hline Mean & $19.67 \mathrm{a}$ & 21.17 a & $11.50 \mathrm{~b}$ & & $20.50 \mathrm{a}$ & $21.67 \mathrm{a}$ & $11.50 \mathrm{~b}$ & \\
\hline $\operatorname{LSD}(0.05)$ & $F=1.448$ & $I=1.506$ & $F \times I=2.609$ & & $F=0.573$ & $I=1.870$ & $F \times I=3.23$ & \\
\hline \multicolumn{9}{|c|}{ Dry weight (g) } \\
\hline $\mathrm{F}_{1}$ (once in 1 day) & $3.10 \mathrm{~b}$ & $4.60 \mathrm{a}$ & $2.00 \mathrm{~d}$ & $3.23 a$ & $4.00 \mathrm{~b}$ & $4.250 \mathrm{a}$ & $2.200 \mathrm{e}$ & $3.48 \mathrm{a}$ \\
\hline $\mathrm{F}_{2}$ (once in 2 days) & $2.45 c$ & $3.10 \mathrm{~b}$ & $1.15 \mathrm{f}$ & $2.23 \mathrm{~b}$ & $3.05 \mathrm{c}$ & $3.050 \mathrm{c}$ & $2.00 \mathrm{f}$ & $2.70 \mathrm{~b}$ \\
\hline $\mathrm{F}_{3}$ (once in 3 days) & $2.050 \mathrm{~d}$ & $2.50 \mathrm{c}$ & $1.750 \mathrm{e}$ & $2.10 c$ & 2.050 ef & $2.450 \mathrm{~d}$ & $1.550 \mathrm{~g}$ & $2.017 \mathrm{C}$ \\
\hline Mean & $2.53 \mathrm{~b}$ & $3.40 \mathrm{a}$ & $1.63 c$ & & $3.033 b$ & $3.25 \mathrm{a}$ & 1.917 c & \\
\hline LSD (0.05) & $F=0.1239$ & $I=0.1012$ & $F \times I=0.175$ & & $F=0.0941$ & $I=0.1631$ & $F \times I=0.163$ & \\
\hline \multicolumn{9}{|c|}{ Leaf area $\left(\mathrm{cm}^{2}\right)$} \\
\hline $\mathrm{F}_{1}$ (once in 1 day) & $71.00 \mathrm{~b}$ & $73.50 \mathrm{a}$ & $38.50 \mathrm{~g}$ & $61.00 a$ & $68.30 \mathrm{a}$ & $68.80 a$ & $38.75 \mathrm{~d}$ & $58.62 \mathrm{a}$ \\
\hline $\mathrm{F}_{2}$ (once in 2 days) & $65.10 \mathrm{~d}$ & 62.65 e & $36.90 \mathrm{~g}$ & $54.88 c$ & $61.35 b$ & $59.60 \mathrm{~b}$ & $37.25 \mathrm{~d}$ & $52.73 \mathrm{C}$ \\
\hline $\mathrm{F}_{3}$ (once in 3 days) & 68.20 & $62.10 \mathrm{e}$ & $43.00 \mathrm{f}$ & $57.77 b$ & $68.50 a$ & $60.75 \mathrm{~b}$ & $42.00 \mathrm{c}$ & $57.08 b$ \\
\hline Mean & $68.10 \mathrm{a}$ & $66.08 \mathrm{~b}$ & $39.47 c$ & & $66.05 a$ & $93.05 \mathrm{~b}$ & $39.33 c$ & \\
\hline LSD (0.05) & $F=1.116$ & $I=1.077$ & $F \times I=1.752$ & & $F=1.139$ & $I=1.139$ & $F \times I=0.97$ & \\
\hline \multicolumn{9}{|c|}{ Plant height $(\mathrm{cm})$} \\
\hline $\mathrm{F}_{1}$ (once in 1 day) & $57.50 \mathrm{abc}$ & $62.50 \mathrm{a}$ & 37.50 e & $52.50 \mathrm{a}$ & $68.00 \mathrm{a}$ & $67.50 \mathrm{a}$ & 33.50 de & $56.33 a$ \\
\hline $\mathrm{F}_{2}$ (once in 2 days) & $58.50 \mathrm{ab}$ & $50.00 \mathrm{bcd}$ & $40.00 \mathrm{de}$ & $49.50 \mathrm{a}$ & $55.00 \mathrm{c}$ & $54.00 \mathrm{c}$ & $35.50 \mathrm{~d}$ & $48.17 b$ \\
\hline $\mathrm{F}_{3}$ (once in 3 days) & 47.50 cde & $56.00 \mathrm{abc}$ & $27.00 \mathrm{f}$ & $43.50 \mathrm{~b}$ & $57.50 \mathrm{~b}$ & $32.50 \mathrm{e}$ & $26.00 \mathrm{f}$ & $38.67 \mathrm{c}$ \\
\hline Mean & $54.50 \mathrm{a}$ & 56.17 a & $34.83 \mathrm{~b}$ & & 60.17 a & $51.33 \mathrm{~b}$ & $31.67 \mathrm{c}$ & \\
\hline LSD (0.05) & $F=5.945$ & $I=5.797$ & $F \times I=9.912$ & & $F=1.364$ & $I=1.364$ & $F \times I=2.36$ & \\
\hline
\end{tabular}

Means followed by the same letter are not significantly different from one another based on Duncan's protected LSD test at $P \leq 0.05$.

Table 7. The influence of irrigation schedule on green bean vegetative growth and pod parameters in the growing season of 2017 and 2018

\begin{tabular}{|c|c|c|c|c|c|c|c|c|}
\hline \multirow{2}{*}{$\begin{array}{l}\text { Irrigation } \\
\text { frequency }\end{array}$} & \multicolumn{4}{|c|}{2017} & \multicolumn{4}{|c|}{2018} \\
\hline & $1.00 \mathrm{ET}\left(\mathrm{I}_{1}\right)$ & $0.80 \mathrm{ET}\left(\mathrm{I}_{2}\right)$ & $0.60 \mathrm{ET}\left(\mathrm{I}_{3}\right)$ & Mean & $1.00 \mathrm{ET}\left(\mathrm{I}_{1}\right)$ & $0.80 \mathrm{ET}\left(\mathrm{I}_{2}\right)$ & $0.60 \mathrm{ET}\left(\mathrm{I}_{3}\right)$ & Mean \\
\hline \multicolumn{9}{|c|}{ Number of branches/plant } \\
\hline $\mathrm{F}_{1}$ (once in 1 day) & $5.00 \mathrm{~b}$ & $5.10 \mathrm{a}$ & $3.00 \mathrm{e}$ & $4.36 \mathrm{~b}$ & $5.050 \mathrm{a}$ & $4.50 \mathrm{ab}$ & $3.00 \mathrm{c}$ & $4.18 \mathrm{a}$ \\
\hline $\mathrm{F}_{2}$ (once in 2 days) & $5.15 \mathrm{a}$ & $4.050 \mathrm{a}$ & $4.10 \mathrm{~cd}$ & $4.43 \mathrm{a}$ & $4.50 \mathrm{ab}$ & $4.00 \mathrm{~b}$ & $4.00 \mathrm{~b}$ & $4.16 \mathrm{a}$ \\
\hline $\mathrm{F}_{3}$ (once in 3 days) & $5.00 \mathrm{~b}$ & $4.150 \mathrm{c}$ & $3.00 \mathrm{e}$ & $4.05 \mathrm{c}$ & $5.050 \mathrm{a}$ & $4.10 \mathrm{~b}$ & $3.15 \mathrm{c}$ & $4.10 \mathrm{a}$ \\
\hline Mean & $5.050 \mathrm{a}$ & $4.433 \mathrm{~b}$ & $3.367 c$ & & $4.86 \mathrm{a}$ & $4.20 \mathrm{~b}$ & $3.38 \mathrm{c}$ & \\
\hline $\operatorname{LSD}(0.05)$ & $F=0.0506$ & $I=0.045$ & $F \times I=0.078$ & & $F=0.4612$ & $I=0.461$ & $F \times I=0.79$ & \\
\hline \multicolumn{9}{|c|}{ Number of pods/plant } \\
\hline $\mathrm{F}_{1}$ (once in 1 day) & $41.00 \mathrm{a}$ & $30.50 \mathrm{bc}$ & $22.00 \mathrm{de}$ & $31.17 \mathrm{a}$ & $39.50 \mathrm{a}$ & $33.50 \mathrm{~b}$ & $23.50 \mathrm{e}$ & $32.17 \mathrm{a}$ \\
\hline $\mathrm{F}_{2}$ (once in 2 days) & $33.50 \mathrm{~b}$ & $32.50 \mathrm{~b}$ & 19.50 ef & $28.50 \mathrm{~b}$ & $33.50 \mathrm{~b}$ & $29.00 \mathrm{c}$ & $20.00 \mathrm{f}$ & $27.50 \mathrm{~b}$ \\
\hline $\mathrm{F}_{3}$ (once in 3 days) & $27.50 \mathrm{c}$ & $23.50 \mathrm{~d}$ & $17.50 \mathrm{f}$ & $22.83 \mathrm{C}$ & $28.50 \mathrm{~cd}$ & $25.50 \mathrm{de}$ & $24.50 \mathrm{e}$ & $26.17 b$ \\
\hline Mean & $34.00 \mathrm{a}$ & $28.83 \mathrm{~b}$ & $19.67 \mathrm{c}$ & & $33.83 \mathrm{a}$ & $29.33 \mathrm{~b}$ & $22.67 c$ & \\
\hline $\operatorname{LSD}(0.05)$ & $F=1.923$ & $I=1.915$ & $F \times I=3.325$ & & $F=1.768$ & $I=1.768$ & $F \times I=3.063$ & \\
\hline \multicolumn{9}{|c|}{ Weight of pods/plant (g) } \\
\hline $\mathrm{F}_{1}$ (once in 1 day) & $161.5 \mathrm{~b}$ & $179.5 \mathrm{a}$ & $101.0 \mathrm{e}$ & $147.3 a$ & $162.5 b$ & $185.0 \mathrm{a}$ & $100.5 e$ & $129.0 a$ \\
\hline $\mathrm{F}_{2}$ (once in 2 days) & $161.0 \mathrm{~b}$ & $139.0 \mathrm{c}$ & $83.00 \mathrm{f}$ & $127.7 b$ & $161.0 \mathrm{~b}$ & $133.5 c$ & $84.50 f$ & $126.8 \mathrm{~b}$ \\
\hline $\mathrm{F}_{3}$ (once in 3 days) & $159.0 \mathrm{~b}$ & $120.5 \mathrm{~d}$ & $73.50 \mathrm{~g}$ & $117.7 \mathrm{c}$ & $160.5 b$ & $115.5 d$ & $70.50 \mathrm{~g}$ & $115.5 c$ \\
\hline Mean & $160.5 \mathrm{a}$ & $146.3 \mathrm{~b}$ & $85.83 c$ & & $141.5 b$ & $144.7 a$ & $85.17 \mathrm{c}$ & \\
\hline $\operatorname{LSD}(0.05)$ & $F=1.742$ & $I=1.688$ & $F \times I=2.861$ & & $F=1.255$ & $I=1.255$ & $F \times I=2.17$ & \\
\hline \multicolumn{9}{|c|}{ mean length of pods $(\mathrm{cm})$} \\
\hline $\mathrm{F}_{1}$ (once in 1 day) & $18.50 \mathrm{a}$ & $16.50 \mathrm{bc}$ & $13.50 \mathrm{~d}$ & $16.17 a$ & $19.00 \mathrm{a}$ & $16.50 \mathrm{bc}$ & $13.50 d$ & $16.33 a$ \\
\hline $\mathrm{F}_{2}$ (once in 2 days) & $17.50 \mathrm{ab}$ & $15.00 \mathrm{~cd}$ & $11.50 \mathrm{e}$ & $14.67 \mathrm{~b}$ & $17.50 \mathrm{ab}$ & $15.50 c$ & $12.50 \mathrm{~d}$ & $15.17 \mathrm{~b}$ \\
\hline $\mathrm{F}_{3}$ (once in 3 days) & $15.00 \mathrm{~cd}$ & $13.50 \mathrm{~d}$ & $10.50 \mathrm{e}$ & $13.00 \mathrm{c}$ & $17.50 \mathrm{ab}$ & $15.50 c$ & $10.50 \mathrm{e}$ & $14.50 \mathrm{~b}$ \\
\hline Mean & $17.00 \mathrm{a}$ & $15.00 \mathrm{~b}$ & $11.83 \mathrm{C}$ & & $18.00 \mathrm{a}$ & $15.83 b$ & $12.17 \mathrm{c}$ & \\
\hline LSD (0.05) & $F=1.021$ & $I=1.003$ & $F \times I=1.738$ & & $F=0.9414$ & $I=0.941$ & $F \times I=1.631$ & \\
\hline
\end{tabular}

Means followed by the same letter are not significantly different from one another based on Duncan's protected LSD test at $P \leq 0.05$ 


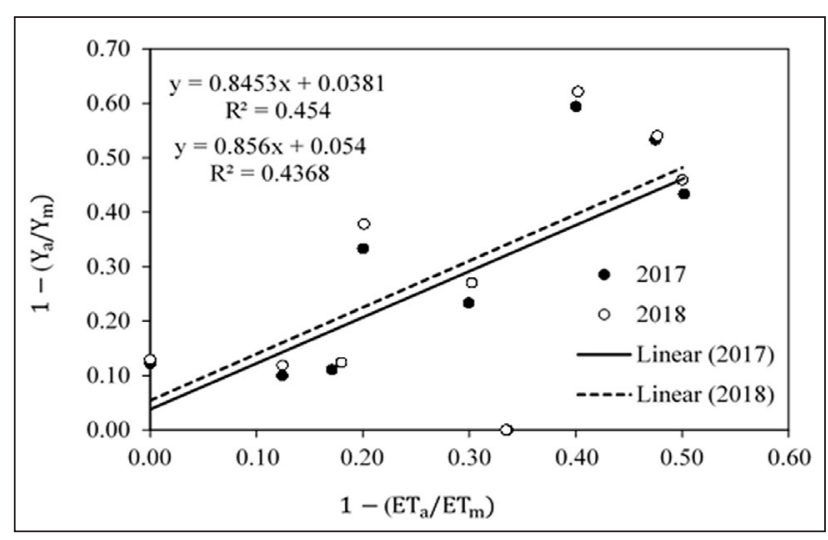

Figure 4. The yield response factor $\left(k_{y}\right)$ for both empirical year

\section{Yield response factor}

Yield response factor specifies the decline in yield resulting from the reduction in water supply. The maximum yield $\left(Y_{\mathrm{a}}\right)$ was achieved by $\mathrm{F}_{1} \mathrm{I}_{2}$ treatment (Table 5 ). The maximum ET values $\left(\mathrm{ET}_{\mathrm{m}}\right)$ were $327.0 \mathrm{~mm}$ and $328.72 \mathrm{~mm}$ for the growing season of 2017 and 2018, respectively. The correlation between the relative decrease in yield $\left(1-Y_{\mathrm{a}} / Y_{\mathrm{m}}\right)$ and the corresponding relative deficit of evapotranspiration (1-ET $/ \mathrm{ET}_{\mathrm{m}}$ ) was linear (Fig. 4) with slopes (yield response factor) of 0.8453 and 0.856 for the growing season of 2017 and 2018, respectively. Nevertheless, the diverse irrigation interval treatments had a significant impact on the yield response factor, since this was $0.50,0.90$ and 1.58 in the growing season of 2017 and $0.54,1.00$ and 1.71 in the growing season of 2018 for $F_{1}$, $\mathrm{F}_{2}$ and $\mathrm{F}_{3}$ treatments, respectively.

For green beans, the reduction in yield is usually proportionally greater with the increment in water deficit. The obtained yield response factor, $k_{y}$, values were 0.8453 in 2017 and 0.856 in 2018 (Fig. 4), which are considered lower than those reported by Sezen et al. (2005), who found that the $k_{y}$ values were 1.15 and 1.23 in the growing season of 2017 and 2018, respectively. The $k_{y}$ values can vary greatly due to climatic changes, crop varieties, crop water management, soil characteristics and irrigation methods, and may be strongly influenced by periods of water stress occurring at critical growth stages of the crop.

\section{Yield-seasonal crop evapotranspiration relationship}

The best fitting relationship between yield and seasonal $\mathrm{ET}_{\mathrm{c}}$ was a positive power equation for the two experimental years: 2017, $Y=49.975 \mathrm{ET}_{\mathrm{c}}^{0.9492}\left(R^{2}=0.4944\right) ; 2018, Y=38.944 \mathrm{ET}_{\mathrm{c}}^{0.9859}$ $\left(R^{2}=0.4786\right)$ (Fig. 5). The power regression coefficients, which illustrate the increment in yield per unit increase in seasonal $\mathrm{ET}_{c}$, were $37.24 \mathrm{~kg} \cdot \mathrm{mm}^{-1}$ in 2017 and $37.03 \mathrm{~kg} \cdot \mathrm{mm}^{-1}$ in 2018 . The intercepts were also very similar for both regression lines. According to the power equations, the basal seasonal $\mathrm{ET}_{\mathrm{c}}$ was necessary for initiating yield production and it was 271.16 and $269.65 \mathrm{~mm}$ in 2017 and 2018 , respectively ( $270.405 \mathrm{~mm}$ on average). Initially, the short irrigation interval with low irrigation regime $\left(\mathrm{F}_{1} \mathrm{I}_{1}\right)$ might indicate that the water volume absorbed by plant roots was less than the volume of water applied, resulting in increasing deep percolation. Subsequently, increasing irrigation interval with low irrigation regime $\left(\mathrm{F}_{3} \mathrm{I}_{1}\right)$ realized a higher amount of water applied than the soil water storage capacity, leading to an increased quantity of deep percolation. In both cases, the roots did not exhaust the volume of water applied, which became deep percolation water.

\section{The relationship between yield and water use efficiency}

The data characterizing the relationship between yield and WUE were fitted to 6 distinct mathematical models: (i) linear,

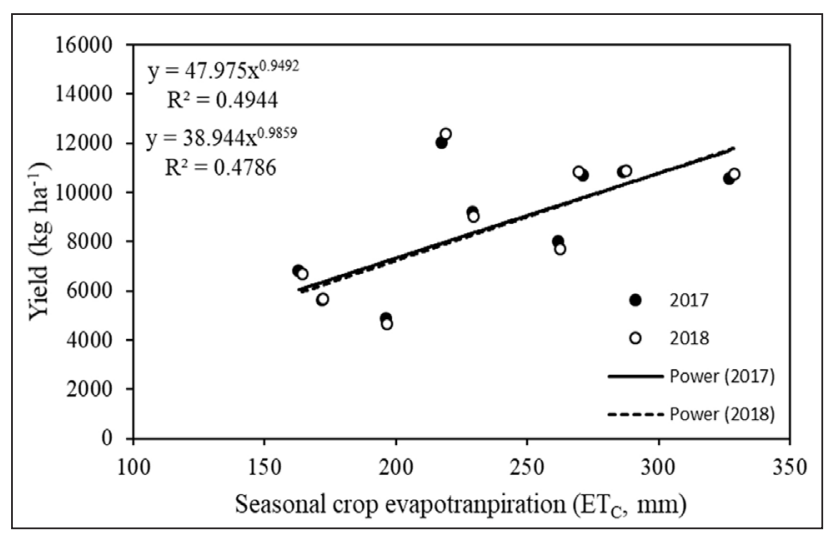

Figure 5. Relationship between seasonal crop evapotranspiration $\left(\mathrm{ET}_{\mathrm{c}}\right)$ and yield for the 2017 and 2018 growing seasons

(ii) quadratic, (iii) cubic, (iv) logarithmic, (v) exponential, and (vi) power. However, based on the values of $R^{2}$, the power equation was determined to be the best-fit model for the relationship between yield and WUE (Fig. 6). According to the power equation, the change in $y$ in relation to $x$ could be defined as the percentage of variation in $y$ for each percentage of variation in $x$. Consequently, when yield was increased by $10 \%$, WUE was increased by $4.7 \%$ and 5.05\% for 2017 and 2018, respectively (Eqs. in Fig. 6).

For the power relationship between yield and water use efficiency (WUE), each point indicates an area, because the volume of water uptake through roots was lower when the irrigation duration was short. The maximum yield and vegetative growth parameters for $\mathrm{F}_{1} \mathrm{I}_{2}$ and $\mathrm{F}_{2} \mathrm{I}_{1}$ could result from the preservation of the ideal moisture content and soil aeration in the root zone and no deep percolation.

When the soil moisture in the root zone is saturated, the oxygen diffusion in soil pores decreases, which affects crop enzyme activity and consequently decreases crop photosynthesis (Abdelaziz and Abdeldaym, 2018). Wan and Kang (2006) reported that this phenomenon would also prohibit leaf surface area expansion. Ultimately, yield-WUE relationships are utilized for determining the ideal irrigation water management method (Chen et al., 2003). The power equation was the best fit for the obtained data with $R^{2}$ values of 0.4528 and 0.5077 in 2017 and 2018, respectively (Fig. 6).

Overall, the outcomes of this research indicate that the yield and WUE of green beans under drip irrigation could be improved through the ideal irrigation schedule. Furthermore, these outcomes indicate that irrigation intervals are useful for determining if the maximum yield can be acquired under adequate and restricted water applications. For example, the minimum yield and vegetative growth parameters were observed in $\mathrm{F}_{1} \mathrm{I}_{1}$ treatment compared to $\mathrm{F}_{1} \mathrm{I}_{2}$ and $\mathrm{F}_{2} \mathrm{I}_{1}$ treatments, where the

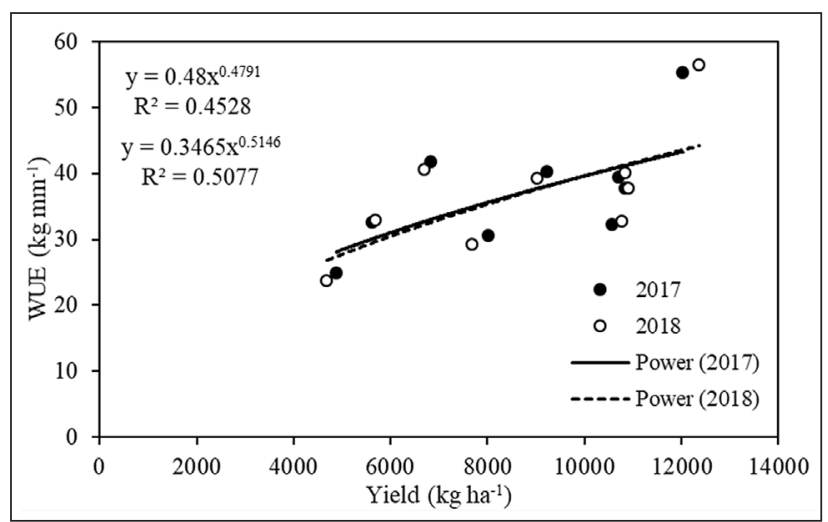

Figure 6. Yield and water use efficiency relationship 
highest yield and vegetative growth parameters were obtained, despite the higher total water volume applied for this treatment. This result might be due to the $\mathrm{F}_{1} \mathrm{I}_{1}$ treatment resulting in the highest soil moisture content in the effective root depth and thus more deep percolation passing the effective root zone (Fig. 5).

\section{CONCLUSIONS}

The obtained results confirmed that the irrigation schedule had a considerable effect on the yield and vegetative growth parameters of drip-irrigated green beans in Egypt. Maximum yields of 12030 $\mathrm{kg} \cdot \mathrm{ha}^{-1}$ and $12364 \mathrm{~kg} \cdot \mathrm{ha}^{-1}$ were obtained for the $\mathrm{F}_{1} \mathrm{I}_{2}$ treatment in 2017 and 2018, respectively. The results indicated that the WUE and IWUE values decreased with the decreasing irrigation interval. Further, the high-volume irrigation regime produced low total yield and low yield components. Therefore, it is recommended that a large irrigation interval with a medium irrigation regime (irrigation interval once every day at $0.80 \mathrm{ET}_{\mathrm{c}}$ irrigation regime, $\mathrm{F}_{1} \mathrm{I}_{2}$ treatment) should be used for drip-irrigated green bean under El-Ayat, El-Giza Governorate conditions. Also, the power model was the best in explaining the relationship between yield and seasonal $\mathrm{ET}_{\mathrm{c}}$ for both growing seasons.

\section{ORCID}

Emad A Abdeldaym

https://orcid.org/0000-0001-6352-1784

\section{REFERENCES}

ABDELAZIZ ME, ABDELSATTAR M, ABDELDAYM EA, ATIA MA, MAHMOUD AWM, SAAD MM and HIRT H (2019) Piriformospora indica alters $\mathrm{Na}^{+} / \mathrm{K}^{+}$homeostasis, antioxidant enzymes and LeNHX1 expression of greenhouse tomato grown under salt stress. Sci. Hortic. 256 (1) 108532. https://doi.org/10.1016/j.scienta.2019.05.059

ABDELAZIZ ME and ABDELDAYM EA (2018) Cucumber growth, yield and quality of plants grown in peatmoss sand as affected by rate of foliar applied postassium. Bioscience. 15 (3) 2871-2879.

ABUARAB ME, EL-MOGY MM, HASSAN AM, ABDELDAYM EA, ABDELKADER NH and EL-SAWY M (2019) The effects of root aeration and different soil conditioners on the nutritional values, yield, and water productivity of potato in clay loam soil. Agronomy. 9 (1) 418. https://doi.org/10.3390/agronomy9080418

ALLEN RG, PEREIRA LS, RAES D and SMITH M) 1998 (Crop evapotranspiration - guidelines for computing crop water requirements. FAO Irrigation and Drainage Paper 56. United Nations Food and Agriculture Organization, Rome. http://www.fao.org/docrep/x049 0e/x0490e00.htm

ASSOULINE S (2002) The effects of microdrip and conventional drip irrigation on water distribution and uptake. Soil Sci. Soc. Am. J. 66 (5) 1630-1636. https://doi.org/10.2136/sssaj2002.1630

ATIA MA, ABDELDAYM EA, ABDELSATTAR M, IBRAHIM DS, SALEH I, ELWAHAB MA, OSMAN GH, ARIF IA and ABDELAZIZ ME (2019) Piriformospora indica promotes cucumber tolerance against root-knot nematode by modulating photosynthesis and innate responsive genes. Saudi J. Biol. Sci. 27 (1) 279-287. https://doi. org/10.1016/j.sjbs.2019.09.007

BOROŠIC J, ROMIC D and DOLANJSKI D (2000) Growth and yield components of dwarf french bean grown under irrigation conditions. Acta Hortic. 533 (1) 451-460. https://doi.org/10.17660/ ActaHortic.2000.533.56

BOUTRAA T and SANDERS FE (2001) Influence of water stress on grain yield and vegetative growth of two cultivars of bean (Phaseolus vulgaris L.). J. Agron. Crop. Sci. 187 (4) 251-257. https:// doi.org/10.1046/j.1439-037X.2001.00525.x

CHEN C, PAYNE WA, SMILEY RW and STOLTZ MA (2003) Yield and water-use efficiency of eight wheat cultivars planted on seven dates in Northeastern Oregon. J. Agron. 95 (1) 836-843. https://doi. org/10.2134/agronj2003.8360

ÇOLAK YB, YAZAR A, GÖNEN E and EROĞLU EÇ (2018) Yield and quality response of surface and subsurface drip-irrigated eggplant and comparison of net returns. Agric. Water Manage. 206 (1) 165 175. https://doi.org/10.1016/j.agwat.2018.05.010
COYAGO-CRUZ E, MELÉNDEZ-MARTÍNEZ AJ, MORIANA A, GIRÓN IF, MARTÍN-PALOMO MJ, GALINDO A, LÓPEZ-PÉRE D, TORRECILLAS A, BELTRÁN-SINCHIGUANO E and CORELL $M$ (2019) Yield response to regulated deficit irrigation of greenhouse cherry tomatoes. Agric. Water Manage. 213 (1) 212-221. https://doi. org/10.1016/j.agwat.2018.10.020

DOORENBOS J and-KASSAM AH (1986) Yield response to water. Irrigation and Drainage Paper 33. http://www.fao.org/3/i2800e/i2 800e.pdf (Accessed 18 March 2019).

EL-HENDAWY SE, EL-LATTIEF EAA, AHMED MS and SCHMIDHALTER U (2008) Irrigation rate and plant density effects on yield and water use efficiency of drip-irrigated corn. Agric. Water Manage. 95 (7) 836-844. https://doi.org/10.1016/j.agwat.2008.02.008

EL-MOGY MM, SALAMA AM, MOHAMED HFY, ABDELGAWAD KF and ABDELDAYM EA (2019) Responding of long green pepper plants to different sources of foliar potassium fertiliser. Agriculture (Polnohospodárstvo). 65 (2) 59-76. https://doi.org/10.2478/agri-20190007

EL-HENDAWY SE and SCHMIDHALTER U (2010) Optimal coupling combinations between irrigation frequency and rate for dripirrigated maize grown on sandy soil. Agric. Water Manage. 97 (3) 439-448. https://doi.org/10.1016/j.agwat.2009.11.002

ERTEK A, ŞENSOY S, KÜÇÜKYUMUK C and GEDIK I (2004) Irrigation frequency and amount affect yield components of summer squash (Cucurbita pepo L.). Agric. Water Manage. 67 (1) 63-76. https://doi.org/10.1016/j.agwat.2003.12.004

FERERES E and SORIANO MA (2007) Deficit irrigation for reducing agricultural water use. J. Exp. Bot. 58 (4) 147-159. https://doi.org/ 10.1093/jxb/erl165

FREED R, EISENSMITH SP, GOETZ S, REICOSKI K, SMAIL VW and WOLBERG P (1989) A microcomputer programme for the design, management and analysis of agronomic research experiments. In: MSTAT-C Users Guide. Michigan State University, East Lansing, MI., USA.

HEERMANN DF (1985) ET in irrigation management. In: National Conference on Advances in Evapotranspiration, 16-17 Dec 1985, Chicago. American Society of Agricultural Engineers. 323-334.

HERGERT GW, MARGHEIM JF, PAVLISTA AD, MARTIN DL, SUPALLA RJ and ISBELL TA (2016) Yield, irrigation response, and water productivity of deficit to fully irrigated spring canola. Agric. Water Manage. 168 (1) 96-103. https://doi.org/10.1016/j.ag wat.2016.02.003

HOWELL TA, CUENCA RH and SOLOMON KH (1990) Crop yield response. In: Management of Farm Irrigation Systems. American Society of Agricultural Engineers, St. Joseph, MI. 93-122.

ISTANBULLUOGLU A (2009) Effects of irrigation regimes on yield and water productivity of safflower (Carthamus tinctorius L.) under Mediterranean climatic conditions. Agric. Water Manage. 96 (12) 1792-1798. https://doi.org/10.1016/j.agwat.2009.07.017

KANBER R, YAZAR A, ÖNDER S and KÖKSAL H (1993) Irrigation response of Pistachio (Pistacea vera L). Irrig. Sci. 14 7-14. https://doi. org/10.1007/BF00195000

KELLER J and KARMEL ID (1975) Trickle irrigation design parameters. Trans. Am. Soc. Agric. Eng. 17 (4) 678-684. https://doi.org/ 10.13031/2013.36936

MAHMOUD AWM, ABDELAZIZ SM, EL-MOGY MM and ABDELDAYM EA (2019) Effect of foliar $\mathrm{ZnO}$ and FeO nanoparticles application on growth and nutritional quality of red radish and assessment of their accumulation on human health. Agriculture (Polnohospodárstvo) 65 (1) 16-29. https://doi.org/10.2478/agri-20190002

PATANÈ C and COSENTINO SL (2010) Effects of soil water deficit on yield and quality of processing tomato under a Mediterranean climate. Agric. Water Manage. 97 (1) 131-138. https://doi.org/10. 1016/j.agwat.2009.08.021

SEZEN SM, YAZAR A, CANBOLAT M, EKER $S$ and CȨLIKEL G (2005) Effect of drip irrigation management on yield and quality of field grown green beans. Agric. Water Manage. 71 (3) 243-255. https://doi.org/10.1016/j.agwat.2004.09.004

SEZENS M, YAZAR A, AKYILDIZ A, DASGAN HY and GENCEL $B$ (2008) Yield and quality response of drip irrigated green beans under full and deficit irrigation. Sci. Hortic. 117 (2) 95-102. https:// doi.org/10.1016/j.scienta.2008.03.032 
SMAJSTRLA AG, BOMAN BJ, HAMAN DZ, PITTS DJ and ZAZUETA FS (1990) Field evaluation of micro irrigation water application uniformity. Florida Cooperative Extension Service, Institute of Food and Agricultural. https://edis.ifas.ufl.edu/pdffiles/AE/AE09400.pdf (Accessed 24 August 2020).

SPEARS TD (2003) Irrigating efficiently to feed the world in 2050. In: Proceedings of the 2003 Irrigation Association International Exposition And Technical Conference, USA. The Irrigation Association, Falls Church, VA. 411-422.

TESTA G, GRESTA F and COSENTINO SL (2011) Dry matter and qualitative characteristics of alfalfa as affected by harvest times and soil water content. Eur. J. Agron. 34 (3) 144-152. https://doi. org/10.1016/j.eja.2010.12.001

UÇAN K, KILLI F, GENÇOĞLAN C and MERDUN H (2007) Effect of irrigation frequency and amount on water use efficiency and yield of sesame (Sesamum indicum L.) under field conditions. Field Crops Res. 101 (3) 249-258. https://doi.org/10.1016/j.fcr.2006.11.011
VWIOKO ED, EL-ESAWI MA, IMONI ME, AL-GHAMDI AA, ALI HM, EL-SHEEKH MM, ABDELDAYM EA and AL-DOSARY MA (2019) Sodium azide priming enhances waterlogging stress tolerance in okra (Abelmoschus esculentus L.). Agronomy. 9 (11) 679. https://doi.org/10.3390/agronomy9110679

WAN S and KANG Y (2006) Effect of drip irrigation frequency on radish (Raphanus sativus L.) growth and water use. Irrig. Sci. 24 161-174. https://doi.org/10.1007/s00271-005-0005-9

ZHANG G, SHEN D, MING B, XIE R, JIN X, LIU C, HOU P, XUE J, CHEN J, ZHANG W, LUI W, WANG K and LI S (2019) Using irrigation intervals to optimize water-use efficiency and maize yield in Xinjiang, northwest China. Crop J. 7 (3) 322-334. https://doi. org/10.1016/j.cj.2018.10.008 